\title{
MOREMI WILDLIFE RESERVE, OKAVANGO
}

\section{By JUNE KaY}

Last October, Oryx published an article on the decimation of fauna in the Okavango Swamp country of the Bechuanaland Protectorate. Now comes the story of the astonishing sequel.

The Batawana tribe, to whom the territory belongs, have created the Moremi Wildlife Reserve in order to preserve the very animals off which they, as a hunting people, must live.

Equally important is the fact that neighbouring tribes are already enquiring for details, with a view to setting up Fauna Preservation Societies and Reserves of their own. The stone thrown into the clear waters of the Okavango is sending out ripples that could become Africa-wide.

The Okavango is one of the richest reservoirs of wildlife left on earth, largely owing to the variety of habitat created by its unique geophysical construction of swamp and semi-desert. The fifty-odd species of mammals to be found within its compass, range from elephant, buffalo and lion at one end of the scale to sitatunga, ant bear, aardwolf and honey ratel at the other. Until very recently it was a happy hunting ground for poachers and instances of appalling cruelty are on record, from the bludgeoning to death of lion cubs in steel jaw-traps set by Masarwa Bushmen, to the use of strychnine by Europeans who were bent upon obtaining skins for re-sale.

My husband Robert and I entered the picture at the end of 1958, bent upon a few months' safari holiday in the amphibious D.U.K.W. that is now our only home. We were, like so many people, misled by the term "Swamp". To us it meant mangrove, snakes and probably mud. What we found was a land of sand and shining water, where black-faced Vervet monkeys chattered and swung in the splendid riverine forests and impala leaped in flowing arcs of red against the sun. In the gently changing seasons of the Swamps we watched the cubs of the previous season grow into shaggy, gangling young lions, watched the young giraffe, all rubber legs and tottering awkwardness, and the tsessebe calves, streaking along in the dust behind their fastest-in-Africa mothers, when every herd smelled of milk and the whole of the Okavango was a wild nursery.

Our "few months" in the area stretched into five years, and the holiday became a way of life. Horrified by the activities of the poachers, Robert set his heart on the formation of a game reserve. Characteristically, he went straight to the roots of the problem.

When Bechuanaland first came under the protection of the Crown it was specifically laid down that the game in tribal territory still belonged to the African owners of the land. The Batawana are an impoverished people, their stamina undermined by malnutrition and disease. The light desert soil is not suitable for agriculture, no mineral wealth has been discovered ; cattle ranching is limited by the presence of the tsetse fly and the incidence of foot and mouth disease. To the Batawana the availability of game animals as a source of food means the difference between life and death. 
"If we stop hunting, we starve," said the tribesmen when Robert first approached them. "This thing cannot be."

With almost every hand against him, my husband persevered doggedly. "I don't ask you to stop hunting altogether," he told the Batawana. "I only ask that you set aside one area for the preservation of your breeding stock. Kill the cow that bears the calf, and to-morrow you will have no meat, neither will your children after you. So it is with the fauna."

Gradually, the truth began to dawn. To the cattle-owners amongst the tribe, it made economic sense. "Kill the cow that bears the calf, and to-morrow you will have no meat. ..." The phrase caught on, was passed from mouth to mouth, and began to go like a grass fire with the wind behind it. The Batawana were awakening from their long sleep. The young Crown Prince, Letsholathebe Moremi, spoke out in favour of the new ideas, and the tribal elders listened. In September, 1962, they invited Robert to attend a meeting of their Kgotla, or Tribal Parliament. Two days later we received official sanction from the Regent, Mahumahadi Elizabeth Moremi, O.B.E., mother of the Prince, for the formation of a multi-racial Fauna Preservation Society in N'gamiland.

On 1st November the inaugural meeting was held, a Committee elected and a Constitution drafted. The Office Bearers included Africans who had, initially, been amongst our most bitter opponents and who had now swung round completely to the idea of game preservation. It was a tremendous step forward, but more was to follow. The decision on the creation of a game reserve had been postponed until the Annual Tribal Council and Kgotla Meetings in March, 1963, and Robert, his African supporters now solidly behind him, worked all out towards this end. Day after day and night after night they poured out fauna preservational propaganda, contacting the tribal elders and headmen of the outlying villages, who returned home to spread the word amongst their own people. The Bayei tribe, from whom the Batawana had conquered the territory, buried their longstanding blood-feud with their victors and came out in common cause to preserve the wildlife off which they both lived. The Masarwa Bushmen and the Hereros followed suit. Dramatically, African women began joining the Fauna Preservation Society of N'gamiland, passing on the new ideals to their children.

Almost before we knew it, March was upon us. On the 12th we attended the meeting of the Tribal Council, and the elders declared in our favour. On the 15th the Kgotla sat-and it was with them that the final decision lay. For the thousands of game animals in the valley of the Kwaai it was "now or never", and the tribesmen knew it. A fortnight later the hunting season was due to open, and if no Reserve was declared by the Kgotla the whole of the Okavango would be thrown open to the professional safari firms.

The meeting was held in the open under the big tree outside the Batawana Administrative Offices, with the white glare beating up from the desert sand and goats and donkeys wandering listlessly from thorny shade to thorny shade. They sat round in a silent ring, twenty deep, the elders and people of the Batawana tribe, eyes intent and skins glistening with 
sweat on this burning-glass of a morning - a hunting people, called to the preservation of their game. In the centre, on chairs, sat the light-skinned Regent, Elizabeth Moremi, with her quick eyes and silky voice; Mr. Eustace Clark, District Commissioner, correct and brisk and, I thought, uncomfortable in a suit; my husband in white tropical kit; myself in jeans. Beside us, faithful to the last, were the men to whom the Fauna Preservation Society of N'gamiland largely owed its being : Jack Ramsden, Chairman, son of a white man and a woman of the proud Herero tribe-Jack the hunter, who had now turned game preservationist; Isaac Tudor, Assistant Secretary, the man who was almost a tribal hero; Michael Dithapo, Treasurer, and cousin to the Crown Prince; Montso Mogalakwe, local Propaganda Officer, who had trudged unweariedly round the villages, spreading what he called his "gospel " of fauna preservation; Rox Ledimo the animal-lover, and Ges Segadimo the sensitive intellectual.

We had thought our work well done, yet for two hours the objectors gave tongue. They must await the return of the Crown Prince, now studying public administration in England; they needed more time to consider the matter of a game reserve; the decision should be postponed for another year.

Robert reached over and scribbled a note in the margin of the Minutes in my lap. "Doesn't look too good." I looked at Jack Ramsden, and he looked away. Michael Dithapo was staring stonily at his hands. . Then I saw Montso Mogalakwe stand up to speak-good, kind old " Mog ", who was known only to speak in adversity. I knew that he would fight for us, for it had come to fighting. He spoke, and sat again.

There was an unearthly hush. Then suddenly, at the command of the Regent, the members of the Tribal Council galvanized into action. One after another, like rays of light from a stormy sky, their verdicts came.

"I support the Reserve. . . . I support the Reserve. . . . I support the Reserve."

Jack Ramsden turned to me and smiled. "You should not have worried so much. The opposition always speaks first. It is the way of the Kgotla. But now the Reserve will go through, and we have saved the Kwaai."

At ten minutes to one on Friday, 15th March, 1963, the Regent rose to her feet. She had heard the words of her people. The majority were in favour. The Reserve was sanctioned.

The Reserve so dramatically created by the Batawana at the historic March Kgotla this year covers an area of approximately 700 square miles and is triangular in shape, bordered along the northern and southern sides by the Kwaai and Xnaragha rivers respectively and on the east by almost impenetrable bush. This area was deliberately chosen by the hunting peoples of the Okavango as being the cream of their game country, and therefore that which should be set aside and preserved for posterity. Within its bounds the animals will be safe from the guns of the hunters for the first time in their history, as soon as the area can be properly policed.

In April I flew home to England in a bid to raise the necessary fundsand they are still most urgently and desperately needed-for installing game guards as a check on poaching and for developing this fantastically 
rich faunal area as a tourist attraction, so that the peoples of the world may share with the Batawana the wonderful heritage that they have had the foresight and courage to preserve. Robert, known now as Ra Tau, Father of Lions, to the tribesmen, remained behind to assist the Batawana in their vast undertaking.

In May the tribesmen voluntarily went up to the new Reserve-it will be known as the Moremi Wildlife Reserve, Okavango-began the demarkation of boundaries and set up "No Shooting" signs.

I have had a letter from Jack Ramsden and what he had to say was indicative of the new attitude of the majority of his fellow tribesmen towards their fauna.

"Robert met a European safari client on Sunday evening," he wrote, " and this man told him that he was wasting his energy in trying to make the African realize the value of his fauna. I am sorry that we did not meet him in person, because hard words would have been spoken. We now realize the value of our fauna, because you and Robert have shown us its true worth. We cannot be compared with people in other African territories who have not been given a chance to appreciate the tremendous heritage inherent in their wildlife-instead, the professional safari companies have convinced them that their game was better dead than alive."

It is commonly held by many people that once total independence comes to Africa it will be the end of her wildlife and in coming forward to ensure the survival of their game animals the Batawana are not only looking well into the future but doing much to boost the morale of nature lovers throughout the world. Their decision is a shining mark in African tribal history. But in the absence of funds they can do little to implement it. If you would like to help in this project please contribute to "Okavango", The World Wildlife Fund, 2 Caxton Street, Westminster, London, S.W. 1, England. 